\title{
Estimation of carbon sinks in chemical weathering in a humid subtropical mountainous basin
}

\author{
TAO Zhen ${ }^{1}$, GAO QuanZhou ${ }^{1,2^{*}}$, WANG ZhenGang ${ }^{3}$, ZHANG ShengHua ${ }^{1}, \mathrm{XIE} \mathrm{ChenJi}^{1}$, \\ LIN PeiSong ${ }^{1}$, RUAN XiaoBing ${ }^{1}$, LI ShuHong $^{1} \&$ MAO HaiRuo ${ }^{1}$ \\ ${ }^{1}$ School of Geography and Planning, Sun Yat-sen University, Guangzhou 510275, China; \\ ${ }^{2}$ Guangdong Provincial Key Laboratory of Mineral Resource \& Geological Processes, Sun Yat-sen University, Guangzhou 510275, China; \\ ${ }^{3}$ Department of Earth and Environmental Science, K.U. Leuven, Celestijnenlaan 200E, 3001 Heverlee, Belgium
}

Received July 5, 2010; accepted November 23, 2010; published online April 13, 2011

\begin{abstract}
The fluvial geochemistry of the mainstream and tributaries of the Zengjiang River was investigated, and the mass balance approach and deduction methods were used to estimate the uptake of atmospheric $\mathrm{CO}_{2}$ through rock chemical weathering. The results showed that the chemical runoff mainly consisted of $\mathrm{HCO}_{3}^{-}, \mathrm{Ca}^{2+}, \mathrm{Na}^{+}$, and dissolved $\mathrm{Si}$, and that silicate mineral weathering was significant, but carbonate mineral weathering was a minor source of dissolved loads in the Zengjiang River basin because of the low amount of interlayered carbonate rock strata in the catchment. The ion composition indicated that atmospheric $\mathrm{CO}_{2}$ was the primary erosive agent for rock chemical weathering in the Zengjiang River basin. The $\mathrm{CO}_{2}$ consumption fluxes caused by rock chemical weathering were $(3.50-3.81) \times 10^{5} \mathrm{~mol} \mathrm{~km}^{-2} \mathrm{a}^{-1}$, which is just lower than that in tropical and subtropical basalt and carbonate regions, and is much higher than that in temperate and cold-temperate regions, indicating that surficial chemical weathering processes in the humid and hot monsoon current influencing the low-middle latitude zone of the Northern Hemisphere constitutes a significant carbon sink in the global biogeochemical cycle.
\end{abstract}

chemical weathering, chemical runoff, biogeochemical cycle, carbon sink, humid subtropical mountainous area

Citation: Tao Z, Gao Q Z, Wang Z G, et al. Estimation of carbon sinks in chemical weathering in a humid subtropical mountainous basin. Chinese Sci Bull, 2011, 56: 3774-3782, doi: 10.1007/s11434-010-4318-6

On geological timescales, chemical weathering of surficial silicate minerals constitutes one of the carbon sinks in the global biogeochemical cycle; this chemical weathering, together with organic carbon burial processes and the Earth's interior processes, regulates atmospheric $\mathrm{CO}_{2}$ levels $[1,2]$, stabilizes the climate by complex feedback mechanisms [3-5], and ensures habitable conditions on the Earth's surface [1]. For example, the Cenozoic cooling may have been caused by a decrease in atmospheric $\mathrm{CO}_{2}$ concentration resulting from increasing chemical weathering driven by global tectonic uplift [6,7]. Since the Industrial Revolution, global climatic system variations have accelerated as a result of increasing atmospheric $\mathrm{CO}_{2}$ levels originating from anthropogenic processes, including fossil fuel combustion,

*Corresponding author (eesgqz@mail.sysu.edu.cn) cement production, and land use conversion. Academia and governments are making efforts to reduce the rate of global environmental change resulting from greenhouse gases emissions. However, because of the complexity of global carbon cycle processes, uncertainty in the global carbon budget [8] and a lack of understanding of the factors linked to the carbon cycle still exist, and not enough attention has been paid to the contribution of rock chemical weathering in the terrestrial carbon sink budget.

Rock chemical weathering rates and the associated $\mathrm{CO}_{2}$ consumption rates are, to a great extent, determined by the lithology of surficial rocks and regional climate [9]. On a global scale, $40 \%$ of the global flux of $\mathrm{CO}_{2}$ consumption is from weathering of $\mathrm{Na}, \mathrm{K}, \mathrm{Ca}$, and $\mathrm{Mg}$ silicates; the rest of the total flux is derived from carbonate chemical weathering [10]. Most parts of the subtropical zone in the Northern 
Hemisphere is desert or semi-desert because of the downdraught wind, whereas evergreen forests are distributed in the southern and eastern parts of Asia because of the prominent hot and humid monsoon current in those regions. Biogeochemical processes and rock chemical weathering processes are more active in southeastern Asia than in other regions in the northern subtropical zone [11,12]. Carbon sinks produced by chemical weathering processes in humid subtropical regions of Asia should therefore not be neglected [11]. The humid subtropical region constitutes onequarter of China's territory but only a few estimates of carbon sinks produced by chemical weathering in large drainage basins have been conducted, in the areas surrounding the Qinghai-Tibet Plateau [13,14] and the Xijiang River basin [11]. Much effort has been put into the study of $\mathrm{CO}_{2}$ consumption in the chemical weathering of carbonate rocks $[15,16]$, but the chemical weathering of silicate rocks has seldom been studied [12]. Here, we have characterized and compiled budgets for the annual carbon sink effects of chemical weathering in the Zengjiang River basin by investigating the water chemistry and using mass balance and deduction methods [17]. Comparisons between the Zengjiang River basin and other basins located at different latitudes and in different tectonic units were conducted.

\section{Study area}

The Zengjiang River is a second tributary of the Pearl River system. From the headwater to its confluence with the Dongjiang (East) River (Figure 1), the total mainstream length of the Zengjiang River is $230 \mathrm{~km}$ and its total fall is $484 \mathrm{~m}$. The total drainage area above the Qilinzui Hydrological Station, located at the basin's lower part, is 2866 $\mathrm{km}^{2}$, accounting for $91 \%$ of the Zengjiang River basin $\left(3160 \mathrm{~km}^{2}\right)$. Granitoid bedrocks (mainly monzonitic granite, biotite granite, potassic granite, granodiorite, and granite porphyry), formed from the late Paleozoic Era to the Meso-

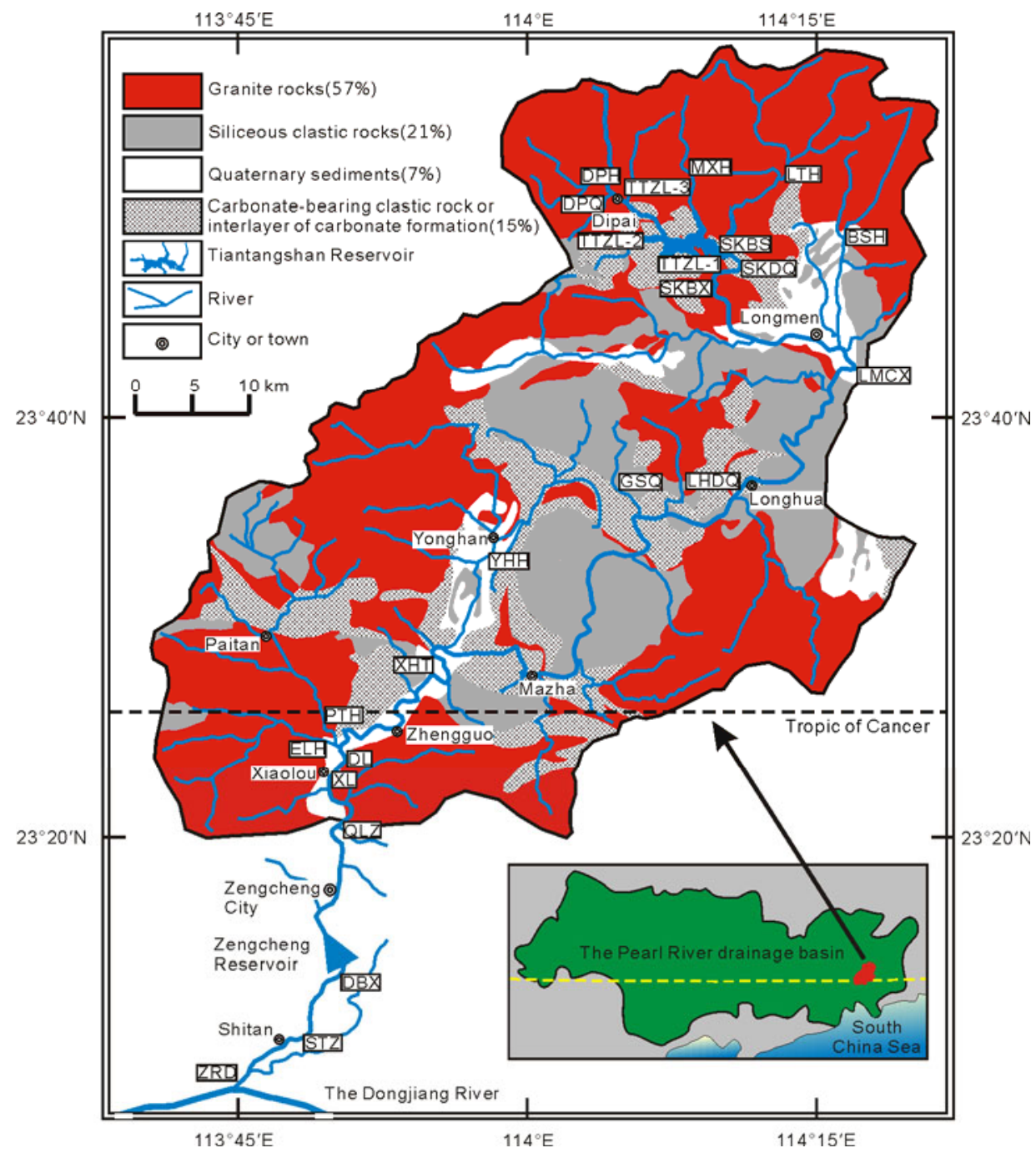

Figure 1 Sketch map of the lithology and river system in the Zengjiang River basin. Letters in rectangular frames represent the sampling sections described in Table 1. 
Table 1 Distribution of sampling sections in the Zengjiang River basin

\begin{tabular}{lcl}
\hline \multicolumn{1}{c}{$\begin{array}{c}\text { Sampling sections along the main } \\
\text { stream of the Zengjiang River }\end{array}$} & $\begin{array}{c}\text { Sampling sections at some tributaries of the mid-lower } \\
\text { reaches of the Zengjiang River }\end{array}$ & $\begin{array}{c}\text { Sampling sections above the } \\
\text { Tiantangshan Reservoir }\end{array}$ \\
\hline Mouth of the Zengiang River (ZRD) & Erlonghe (ELH) & The bridge of the reservoir (SKDQ) \\
Shitan Town (STZ) & Paitanhe (PTH) & Upper the dam of the reservoir (SKBS) \\
Below the Zengcheng Dam (DBX) & Yonghanhe (YHH) & Lower the dam of the reservoir (SKBX) \\
Qilinzui Hydrological Gauge Station (QLZ) & Gaoshaqiao (GSQ) & Tributary 1 of the reservoir (TTZL-1) \\
Xiaolou (XL) & Baishahe (BSH) & Tributary 2 of the reservoir (TTZL-2) \\
Dalou (DL) & & Dipaiqiao (DPQ) \\
Xihutan (XHT) & & Dipaihe (DPH) \\
Longhua Bridge (LHDQ) & Tributary 3 of the reservoir (TTZL-3) \\
Below Longmen Town (LMCX) & Mixihe (MXH) \\
& & Lantianhe (LTH) \\
\hline
\end{tabular}

zoic Era, constitute $57 \%$ of the total drainage area. Mesozoic clastic rocks (mudrock, silty mudrock, sandstone, gravelly sandstone, and volcaniclastic rock) comprise $21 \%$ of the total drainage area. The upper Paleozoic interlayered carbonate rocks or carbonate-bearing clastic rocks (mainly shale sandwiched with limestone or dolomitic limestone, marl and calcareous-argillaceous siltstone) represent $15 \%$ of the total drainage area. The remaining area $(7 \%)$ is carbonate-free Quaternary sediments, which are distributed on the narrow piedmont and valley plains. The landforms within the basin are dominated by mid-low mountains and hills covered with thick layers of red weathering crusts on their top surface. The zonal soil is composed mainly of Udic Ferralisols, with parts of the mountainous areas having Perudic Ferralisols and Gleysol-paddy soils. The Tropic of Cancer runs through the southern part of the basin. The mean annual temperature and precipitation are $21.6^{\circ} \mathrm{C}$ and 2188 mm, respectively (Mazha Weather Station, Figure 1). The zonal vegetation is southern subtropical evergreen broad-leaved forest. Forest coverage ranges from $65 \%$ to $70 \%$, but cropland comprises merely $8.7 \%$ of the drainage area. Water and soil losses are slight. The runoff is primarily rain-fed. Thus, the distribution of flow within the year is determined mainly by the amount of precipitation and its distribution in time. The mean annual flow at the Qilinzui Hydrological Station is $(1.18-6.60) \times 10^{9} \mathrm{~m}^{3}$, with an average of $3.82 \times 10^{9} \mathrm{~m}^{3}$ from 1954 to 2009 ; discharge during the flood season (April-September) accounts for $67 \%-89 \%$ of the total flow, with an average of $83.3 \%$. The river system is complex, and many reservoirs have been constructed within the basin.

\section{Materials and methods}

\subsection{Sampling}

Water samples were collected monthly at the Qilinzui (QLZ) section from December 2008 to January 2010. The chosen sampling position was $0.5 \mathrm{~m}$ below the water surface of the middle channel. Twenty-four sampling sections (Figure 1, Table 1) were also chosen in the mainstream and its tribu- taries, and upstream sampling was conducted in these sections in July 2009 (flood season) and January 2010 (dry season).

\subsection{Analyses}

$\mathrm{HCO}_{3}^{-}$concentrations were determined in situ by titration with diluted $\mathrm{HCl}$ solution; the endpoint was $\mathrm{pH}$ 4.2. Water temperature $(T), \mathrm{pH}$, and electrical conductivity were measured using an Ultrameter ${ }^{\mathrm{TM}}$ Model 6P (Myron L Company, Carlsbad, CA, USA). River water samples in acid-cleaned 1 $\mathrm{L}$ glass bottles were shipped to the laboratory and filtered through a Whatman GF/F filter (Whatman, Maidstone, UK) for ion analysis. The samples were stored in a refrigerator $\left(4^{\circ} \mathrm{C}\right)$, and ion analysis was carried out within 1 week of sampling.

$\mathrm{Ca}^{2+}, \mathrm{Mg}^{2+}, \mathrm{K}^{+}, \mathrm{Na}^{+}$, and dissolved $\mathrm{Si}$ concentrations were analyzed by inductively coupled plasma atomic emission spectrometry (ICP-AES) using an IRIS Advantage spectrometer (Thermo Jarrell Ash Corporation, Franklin, MA, USA). $\mathrm{Cl}^{-}, \mathrm{SO}_{4}^{2-}$, and $\mathrm{NO}_{3}^{-}$concentrations were analyzed by ion chromatography (IC) (D900, Dionex Corporation, Sunnyvale, CA, USA). The average analytical precision was better than $0.5 \%$ for ions and dissolved $\mathrm{Si}$.

Discharge data were obtained from the Guangdong Hydrological Bureau. The coverage area for various rocks within the basin was calculated using ArcGIS software (ESRI, version 9.3).

\section{Results and discussions}

\subsection{Hydrochemical characteristics}

The water in the Zengjiang River basin is neutral to mildly alkaline, with $\mathrm{pH}$ values higher than 7.0 for most samples (Tables 2 and 3 ).

The reliability of water chemical data or the pollution conditions of natural water can be tested by the balance between the positive and negative electrical charges on its inorganic components [18]. Under conditions of no anthropogenic pollution, the riverine positive charge can be expressed 
as $\mathrm{TZ}^{+}=2\left(\mathrm{Ca}^{2+}+\mathrm{Mg}^{2+}\right)+\mathrm{Na}^{+}+\mathrm{K}^{+}$, and the riverine negative charge can be expressed as $\mathrm{TZ}^{-}=\mathrm{HCO}_{3}^{-}+2 \times \mathrm{SO}_{4}^{2-}+$ $\mathrm{Cl}^{-}$(see [19]). The inorganic electrical charge balance index $(e)$ is then calculated as:

$$
e=\left(\mathrm{TZ}^{+}-\mathrm{TZ}^{-}\right) / \mathrm{TZ}^{+} .
$$

For most of the samples, the total dissolved cationic electrical charge was balanced by the total dissolved anionic electrical charge $(10 \%>e>-10 \%)$. The $\mathrm{TZ}^{+}$value of the Zengjiang River is close to the averaged $\mathrm{TZ}^{+}$for rivers globally $(\sim 1250 \mu \mathrm{Eq}$, see [20]), indicating that the main source of the dissolved loads is rock chemical weathering within the basin. However, for a few samples, the absolute values of $e$ are higher, e.g. the sample (LMCX) collected from the mainstream in the low-water period had a higher absolute $e$ value ( $e=-52.99 \%$ ); this is because organic acids in sewage and industrial effluents from Longmen Town, which is the largest residential area in the mid-upper reaches of the Zengjiang River basin, may have a significant effect on the aquatic electrical charge balance. In the LHDQ section, $25 \mathrm{~km}$ from the $\mathrm{LMCX}$ section, $\mathrm{TZ}^{+}$was again balanced by $\mathrm{TZ}^{-}$, indicating that the labile organic pollutants had been decomposed.

For the sample collected in the SKDQ section in the dry season, the $e$ value also deviated from balance $(e=$ $-47.10 \%)$; this can be attributed to the fact that the river bed above the SKDQ section had turned to swamp as a result of construction of the Tiantangshan Reservoir, and this favored an increase in the amount of dissolved organic substances.

The major ions composition and low conductivity (94.19 $\mu \mathrm{S} \mathrm{cm} \mathrm{cm}^{-1}$, which is lower than the global mean value) indicate that silicate mineral chemical weathering is dominant and that carbonate mineral weathering is a secondary source of the dissolved loads in the Zengjiang River (Tables 2 and 3 , Figure 2). $\mathrm{HCO}_{3}{ }^{-}$was the most abundant anion in all the water samples; dissolved Si (except for the sample collected at ZRD in July, and samples collected at ZRD, STZ, DBX, and ELH in January) was the second most abundant. $\mathrm{Ca}^{2+}$ was the most abundant cation, followed by $\mathrm{Na}^{+}$. The abundances of the other ions, in terms of molar concentration, were $\mathrm{Cl}^{-}>\mathrm{SO}_{4}^{2-}>\mathrm{K}^{+}>\mathrm{Mg}^{2+}>\mathrm{NO}_{3}^{-}$.

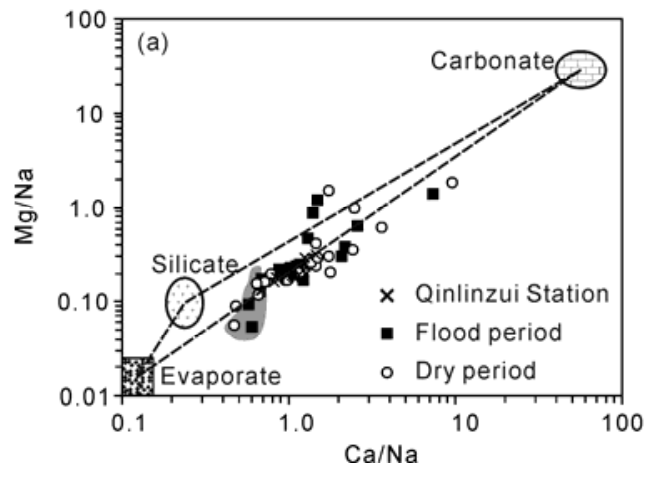

The chemical compositions of the samples (DPH, MXH, LTH, and TTZL-3) collected from the upper tributaries above the Tiantangshan Reservoir were close to the silicate end member (the shaded area in Figure 2); the $\mathrm{HCO}_{3}^{-} / \mathrm{Na}^{+}$ ratio ranged from 1.69 to 2.88 , coinciding with the chemical signature of silicate-draining rivers $\left(\mathrm{HCO}_{3}^{-} / \mathrm{Na}^{+}=2 \pm 1\right.$ [10]). The sample TTZL-2 tended to the carbonate end member, with a $\mathrm{HCO}_{3}{ }^{-} / \mathrm{Na}^{+}$ratio from 12.64 to 16.01 (rivers draining only carbonates have $\mathrm{HCO}_{3}^{-} / \mathrm{Na}^{+}$ratios close to 120 [10]); this can be explained by the carbonate-bearing base rocks above the TTZL-2 section, i.e. shale sandwiched with limestone and calcareous-argillaceous siltstone. The $\mathrm{HCO}_{3}{ }^{-} / \mathrm{Na}^{+}$ratio for the GSQ sample ranged from 3.03 to 5.35 as a result of drainage through areas with silicate rocks, calcareous-argillaceous siltstone, and some lesser carbonate-bearing strata. Note that these results imply that the chemical composition of the river water is constrained by the lithology within the basin.

For all samples, the presence of $\mathrm{Cl}^{-}, \mathrm{SO}_{4}^{2-}$, and $\mathrm{NO}_{3}^{-}$was evidence of the influence of sea-salt and anthropogenic activities on the chemical composition of the river water.

\subsection{Solute dilution in surface water by rain runoff}

The conductivity of the water body during the high-water period was only $60 \%-70 \%$ of that during the low-water period at the lower and middle reaches of the Zengjiang River mainstream (Figure 3). This shows that solutes respond to the dilution effect of rainfall runoff. There was no apparent difference between the solute concentrations in the wet and dry seasons for the upper steeper mountainous tributaries (shaded parts in Figure 3) above the Tiantangshan Reservoir. This was also evidence for the dilution effect of rain runoff on the solute, because it was a rainy day when those samples were collected in January 2010.

The dilution and concentration effects are different for different solutes. For example, the concentration of dissolved $\mathrm{Si}$ is higher in the hot flood season (average $211.45 \mu \mathrm{mol} \mathrm{L}{ }^{-}$) than in the cool dry season (average $195.41 \mu \mathrm{mol} \mathrm{L}{ }^{-1}$ ), implying that the higher atmospheric temperature and plentyful

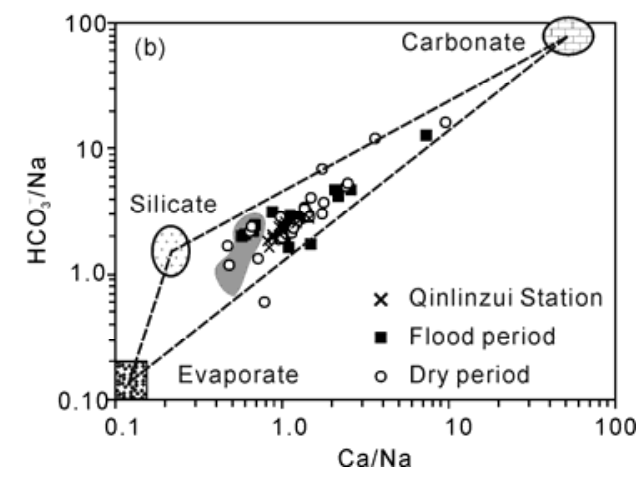

Figure 2 Relationships between element ratios in runoffs, normalized with respect to $\mathrm{Na}$ [10]. 


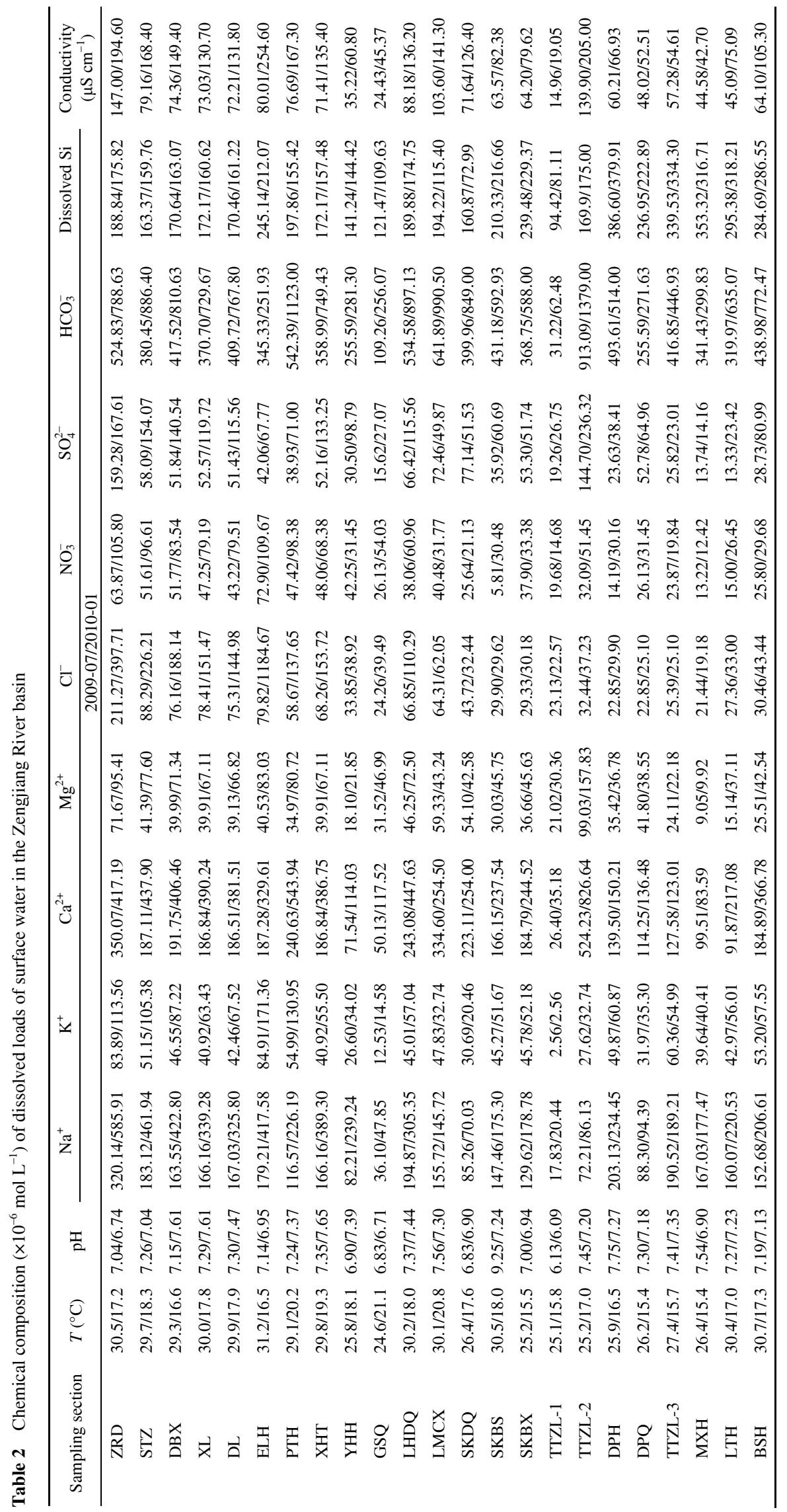


Table 3 Chemical composition $\left(\times 10^{-6} \mathrm{~mol} \mathrm{~L}^{-1}\right)$ of dissolved loads of river water at the Qilinzui Hydrological Gauge Station

\begin{tabular}{|c|c|c|c|c|c|c|c|c|c|c|c|c|}
\hline Sampling date & $T\left({ }^{\circ} \mathrm{C}\right)$ & $\mathrm{pH}$ & $\mathrm{Na}^{+}$ & $\mathrm{K}^{+}$ & $\mathrm{Ca}^{2+}$ & $\mathrm{Mg}^{2+}$ & $\mathrm{Cl}^{-}$ & $\mathrm{NO}_{3}^{-}$ & $\mathrm{SO}_{4}^{2-}$ & $\mathrm{HCO}_{3}^{-}$ & Dissolved Si & $\begin{array}{c}\text { Conductivity } \\
\left(\mu \mathrm{S} \mathrm{cm}^{-1}\right)\end{array}$ \\
\hline $2008-12$ & 16.9 & 7.70 & 270.12 & 51.15 & 288.44 & 49.70 & 127.49 & 45.00 & 76.10 & 632.13 & 157.06 & 104.60 \\
\hline 2009-01 & 13.8 & 7.76 & 358.86 & 58.32 & 346.57 & 71.14 & 144.13 & 37.58 & 96.71 & 852.79 & 180.59 & 122.50 \\
\hline 2009-02 & 20.5 & 9.10 & 295.35 & 58.83 & 311.14 & 66.94 & 110.85 & 29.03 & 74.75 & 777.97 & 169.48 & 112.50 \\
\hline 2009-03 & 16.7 & 7.58 & 387.56 & 102.56 & 325.86 & 70.77 & 206.75 & 101.28 & 143.66 & 636.72 & 184.44 & 131.10 \\
\hline 2009-04 & 23.4 & 8.59 & 369.73 & 71.61 & 326.86 & 67.89 & 150.90 & 70.96 & 122.84 & 715.74 & 185.04 & 136.30 \\
\hline 2009-06 & 25.6 & 6.61 & 146.59 & 60.11 & 211.36 & 46.90 & 77.00 & 70.32 & 66.42 & 410.82 & 143.53 & 78.99 \\
\hline 2009-07 & 32.5 & 7.99 & 187.91 & 73.41 & 192.23 & 43.04 & 88.00 & 64.51 & 51.74 & 460.49 & 175.89 & 89.8 \\
\hline 2009-08 & 31.4 & 8.35 & 205.31 & 63.43 & 257.50 & 60.44 & 93.08 & 52.42 & 66.00 & 581.64 & 191.70 & 94.65 \\
\hline 2009-09 & 31.8 & 7.90 & 279.25 & 67.27 & 284.45 & 56.20 & 131.44 & 47.42 & 87.97 & 638.20 & 184.76 & 107.80 \\
\hline 2009-10 & 27.3 & 7.25 & 346.24 & 54.99 & 285.69 & 55.79 & 162.47 & 33.55 & 101.09 & 644.92 & 175.96 & 116.10 \\
\hline 2009-11 & 25.8 & 8.78 & 354.07 & 57.29 & 309.90 & 64.35 & 157.67 & 32.42 & 101.29 & 737.21 & 170.87 & 122.80 \\
\hline $2009-12$ & 19.4 & 7.27 & 398.87 & 84.15 & 420.68 & 75.70 & 182.50 & 62.74 & 122.84 & 953.77 & 169.91 & 146.80 \\
\hline
\end{tabular}

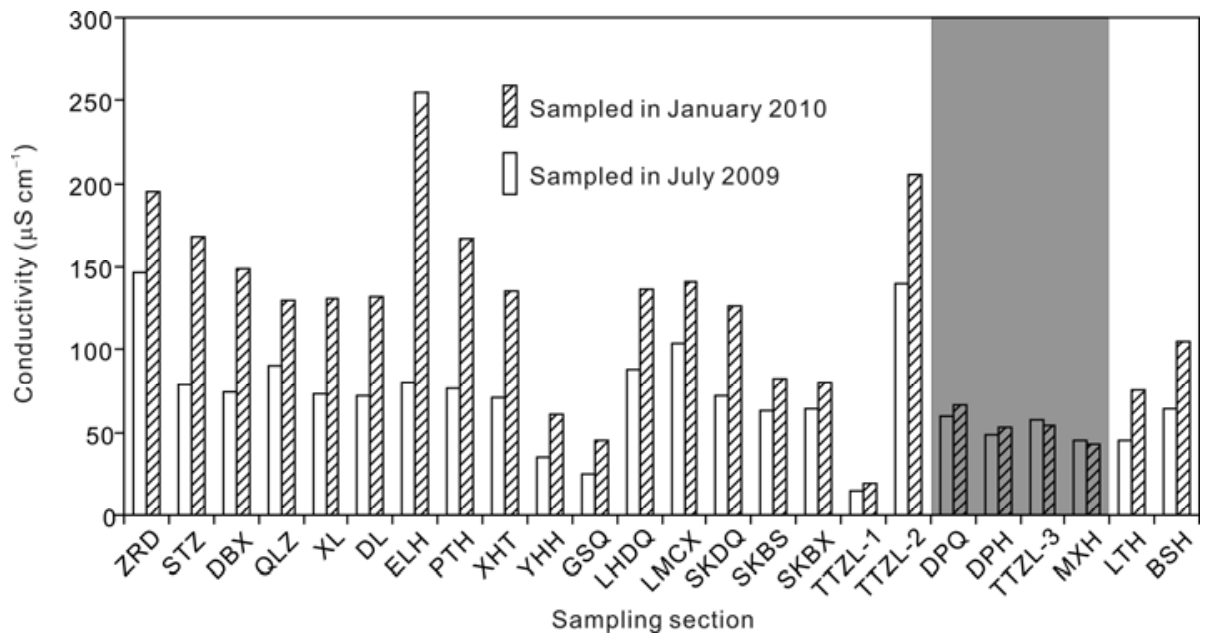

Figure 3 Comparison of electrical conductivity of water in the Zengjiang River in the flood and dry seasons.

precipitation accelerate the chemical weathering of silicate minerals [21]. The dilution effect of rain runoff on the other ions is evident.

\subsection{Contribution of different minerals to chemical weathering within the basin}

On the catchment scale, the erodibility of carbonate minerals is some seven times higher than that of silicate minerals for humid and tropical basins [22]. The river water conductivity would therefore be sharply enhanced if there were sparse carbonate rocks or interlayers of carbonate strata within the basin [23-25]. The conductivities of the water in the Zengjiang River basin and in other basins are listed in Table 4.

The contribution of $\mathrm{Cl}^{-}$to $\mathrm{TZ}^{-}$is regarded as being the contribution of sea-salt to the river water conductivity. After deducting the sea-salt contribution, the main source of river water conductivity is chemical weathering of silicate minerals and carbonate minerals. On the basis of the difference in conductivity between river water from a single granite watershed and water from the Zengjiang River basin (Qinlinzui sampling section; Table 4), the contribution of carbonate minerals weathering products $\left(x_{\text {car }}\right)$ to water in the Zengjiang River basin can be expressed as

$$
x_{\text {car }}(\%)=100 \times\left[\frac{C_{\text {total }}}{C_{\text {sil }}}-1\right] / 6,
$$

where $C_{\text {total }}$ is the total conductivity of the river water and $C_{\text {sil }}$ represents the conductivity of river water from a single silicate rock watershed. The $\mathrm{Cl}^{-}$contributions are excluded from both $C_{\text {total }}$ and $C_{\text {sil }}$. The constant 6 in formula (2) is deduced from following equations:

$$
C_{\text {total }}=x_{\text {car }} \times C_{\text {car }}+\left(1-x_{\text {car }}\right) \times C_{\text {sil }} \text { and } C_{\text {car }}=7 C_{\text {sil }} \text {, }
$$

where $C_{\text {car }}$ is the conductivity of carbonate-draining river water. The values of $x_{\text {car }}$ are calculated to be from $6.03 \%$ to $14.65 \%$ during the flood season, and from $9.97 \%$ to $21.90 \%$ during the dry season. Thus, the contribution of silicate minerals to the conductivity of the river water is from 
Table 4 Comparison of electrical conductivities of water from basins with different lithologies

\begin{tabular}{|c|c|c|c|}
\hline Lithology and sampling section & & The range of conductivity (July-January, $\mu \mathrm{S} \mathrm{cm}^{-1}$ ) & $\mathrm{Cl}^{-} / \mathrm{TZ}^{-}$(July-January, \%) \\
\hline \multirow{4}{*}{$\begin{array}{l}\text { Granite watershed, the upper } \\
\text { part of the Zengjiang River } \\
\text { Basin }\end{array}$} & DPH & $60.21-66.93$ & $3.95-4.59$ \\
\hline & DPQ & $48.02-52.51$ & $5.57-5.48$ \\
\hline & LTH & $45.09-75.09$ & $7.03-4.31$ \\
\hline & MXH & $44.58-42.70$ & $5.31-4.45$ \\
\hline \multicolumn{2}{|c|}{ Longyagou granite watershed, Zhuhai City [12] } & $27.19-78.59$ & $19.62-40.08$ \\
\hline \multicolumn{2}{|c|}{$\begin{array}{l}\text { The Xijiang River basin above Wuzhou section, } \\
\text { with } 47 \% \text { of area covering with carbonate rocks [11] }\end{array}$} & $222.07-307.67$ & $2.00-5.39$ \\
\hline \multirow{4}{*}{$\begin{array}{l}\text { The sampling sections in the middle and } \\
\text { lower reaches of the Zengjiang River }\end{array}$} & XHT & $71.41-135.40$ & $12.25-12.42$ \\
\hline & DL & $72.21-131.80$ & $11.93-11.85$ \\
\hline & $\mathrm{XL}$ & $73.03-130.70$ & $13.04-12.62$ \\
\hline & QLZ & $89.80-129.80$ & $12.28-11.52$ \\
\hline
\end{tabular}

$85.35 \%$ to $93.97 \%$ during the flood season and from $78.10 \%$ to $90.03 \%$ during the dry season. Clearly, the aquatic chemistry is mainly determined by the chemical weathering of silicate minerals within the basin. A sample (TTZL-2) with a higher $\mathrm{Ca}^{2+}$ level, collected in the dry season, may be the result of underground water passing through interlayers of carbonate rocks.

The insignificant contribution of carbonate mineral weathering to the conductivity of water in the Zengjiang River indicates the low proportion of carbonate minerals in the carbonate-bearing stratum within the basin. Thick pure carbonate strata, even though their outcrop is minor within the basin, would account for the main carbonate contribution to the solute concentration in the river water [24-26].

\subsection{Sources of acidic erosion agents}

The total cationic charge $\left(\mathrm{TZ}^{+}\right)$from silicate mineral weathering and the total anionic charge $\left(\mathrm{TZ}^{-}\right)$from erosion agents should basically be balanced in mountain rivers slightly affected by organic acids [12,27]. In the mainstream and tributaries of the Zengjiang River, $\mathrm{TZ}^{+}$was balanced by neither $\mathrm{HCO}_{3}^{-}$nor the sum of $\mathrm{SO}_{4}^{2-}$ and $\mathrm{NO}_{3}^{-}$(Figure 4(a)), but was almost balanced by the sum of $\mathrm{HCO}_{3}^{-}, \mathrm{SO}_{4}^{2-}$, and $\mathrm{NO}_{3}^{-}$(Figure 4(b)). This indicates that $\mathrm{H}_{2} \mathrm{CO}_{3}, \mathrm{H}_{2} \mathrm{SO}_{4}$, and $\mathrm{HNO}_{3}$ are the erosion agents in chemical weathering in the Zengjiang River basin. Acid precipitation is the main source of $\mathrm{SO}_{4}^{2-}$ and $\mathrm{NO}_{3}^{-}$in river water. For instance, during the

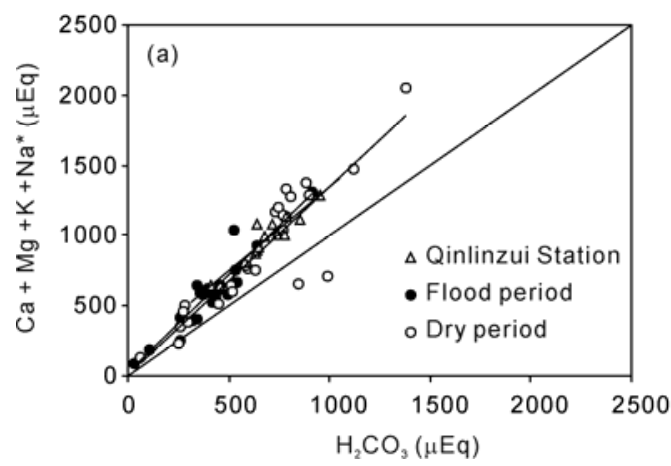

period from June 2005 to April 2007, the $\mathrm{pH}$ values of rainwater ranged from 3.32 to 7.03 (with an average of 4.35 for 371 samples) in Guangzhou, and from 3.38 to 6.49 (with an average of 4.51) in a suburb of Zhuhai. In Luhe County, Guangdong Province, the $\mathrm{pH}$ values of rainwater varied from 4.42 to 5.74 (with an average of 4.88) and the mean $\mathrm{NO}_{3}^{-}$and $\mathrm{SO}_{4}^{2-}$ contents were $24.31 \mu \mathrm{mol} \mathrm{L} \mathrm{L}^{-1}$ and 17.71 $\mu \mathrm{mol} \mathrm{L}{ }^{-1}$, respectively, from May to July 2009. Minor pyrite components in crystalline rocks or clastic sedimentary rocks are also a $\mathrm{SO}_{4}^{2-}$ source in river water [11].

\subsection{Atmospheric $\mathrm{CO}_{2}$ consumption flux}

The chemical weathering processes caused by dilute $\mathrm{H}_{2} \mathrm{SO}_{4}$ and $\mathrm{HNO}_{3}$ solutions do not consume atmospheric $\mathrm{CO}_{2}$; however, $\mathrm{HCO}_{3}^{-}$is produced during weathering of carbonate minerals $[28,29]$. In the chemical weathering processes produced by $\mathrm{H}_{2} \mathrm{CO}_{3}$ as the erosive agent, $1 \mathrm{~mol}$ atmospheric $\mathrm{CO}_{2}$ is consumed when 2 mol $\mathrm{HCO}_{3}^{-}$are produced [22]. All $\mathrm{HCO}_{3}^{-}$is sourced from atmospheric and soil $\mathrm{CO}_{2}$ in the chemical weathering of silicate minerals.

The molar concentration of $\mathrm{HCO}_{3}^{-}$sourced by chemical weathering from atmospheric and soil $\mathrm{CO}_{2}$ in the Zengjiang River basin can be expressed as:

$$
\begin{aligned}
{\left[\mathrm{HCO}_{3}^{-*}\right] } & =\left[\mathrm{HCO}_{3}^{-}\right]_{\text {silicate }}^{\mathrm{H}_{2} \mathrm{CO}_{3}}+0.5 \times\left[\mathrm{HCO}_{3}^{-}\right]_{\text {carbonate }}^{\mathrm{H}_{2} \mathrm{CO}_{3}} \\
& =\left(\left[\mathrm{HCO}_{3}^{-}\right]-\left[\mathrm{HCO}_{3}^{-}\right]_{\text {carbonate }}^{\mathrm{H}_{2} \mathrm{SO}_{4}+\mathrm{HNO}_{3}}\right) \times\left(1-0.5 x_{\text {car }}\right),
\end{aligned}
$$

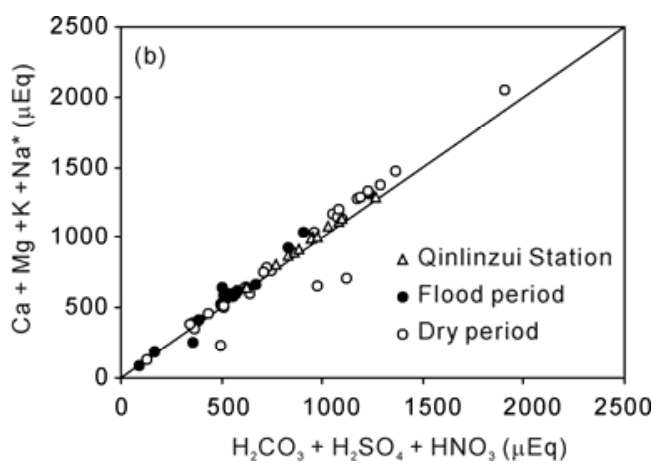

Figure 4 Relationship between total cationic and erosion agent charges in river water. 
where the square brackets denote molar concentration, the subscripts to the square brackets are the weathered mineral, the superscripts to the square brackets are the erosive agent, $\left[\mathrm{HCO}_{3}^{-}\right]$is the molar concentration of $\mathrm{HCO}_{3}^{-}$in the Qilinzui sampling section (Table 3), and $x_{\text {car }}$ is the contribution (\%) of carbonate mineral weathering to the riverine ions, as calculated from formula (2).

$$
\left[\mathrm{HCO}_{3}^{-}\right]_{\text {carbonate }}^{\mathrm{H}_{2} \mathrm{SO}_{4}+\mathrm{HNO}_{3}}=15 \% \times\left(2\left[\mathrm{SO}_{4}^{2-}\right]+\left[\mathrm{NO}_{3}^{-}\right]\right),
$$

where $15 \%$ is the proportion of the carbonate-bearing stratum outcrop within the basin above the Qilinzui sampling section. Given that $\mathrm{H}_{2} \mathrm{SO}_{4}$ and $\mathrm{HNO}_{3}$ are entirely consumed in the weathering of carbonate minerals, $\left[\mathrm{SO}_{4}^{2-}\right]$ and $\left[\mathrm{NO}_{3}^{-}\right]$ are the molar concentrations in the Qilinzui sampling section (Table 3).

Combining formula (4) with formula (3)

$$
\begin{aligned}
{\left[\mathrm{HCO}_{3}^{-*}\right]=} & \left(\left[\mathrm{HCO}_{3}^{-}\right]-15 \% \times\left(2\left[\mathrm{SO}_{4}^{2-}\right]+\left[\mathrm{NO}_{3}^{-}\right]\right)\right) \\
& \times\left(1-0.5 x_{\text {car }}\right) .
\end{aligned}
$$

The annual consumption (Total) and flux of atmospheric and soil $\mathrm{CO}_{2}$ in chemical weathering processes in the Zengjiang River basin is calculated as

$$
\begin{gathered}
\text { Total }=\sum_{i=1}^{365}\left(\left[\mathrm{HCO}_{3}^{-*}\right]_{i} \times \mathrm{Flow}_{i}\right), \\
\text { Flux }=\frac{\text { Total }}{A},
\end{gathered}
$$

where Flow $_{i}$ represents the daily discharge in the Qilinzui sampling section, and $A$ is the area of the basin above the Qilinzui sampling section $\left(2866 \mathrm{~km}^{2}\right)$.

According to eqs. (6) and (7), the annual total consumption and flux of atmospheric $\mathrm{CO}_{2}$ in chemical weathering in the Zengjiang River basin were $(10.02-10.92) \times 10^{8} \mathrm{~mol}$ and $(3.50-3.81) \times 10^{5} \mathrm{~mol} \mathrm{~km}{ }^{-2} \mathrm{a}^{-1}$, respectively. Taking into account that the annual discharge $\left(2.13 \times 10^{9} \mathrm{~m}^{3}\right)$ in 2009 was merely $55.76 \%$ of the mean annual flow $\left(3.82 \times 10^{9} \mathrm{~m}^{3}\right)$ over the years (1954-2009), the calculated uptake flux of atmospheric $\mathrm{CO}_{2}$ by chemical weathering may have been underestimated for the Zengjiang River basin. However, the calculated value is still higher than the global average uptake flux of atmospheric $\mathrm{CO}_{2}\left(2.46 \times 10^{5} \mathrm{~mol} \mathrm{~km}^{-2} \mathrm{a}^{-1}\right.$ [10]).

A comparison of the uptake of atmospheric $\mathrm{CO}_{2}$ during rock chemical weathering in the Zengjiang River basin with uptakes in other basins located in different bio-climate zones is shown in Figure 5.

The atmospheric $\mathrm{CO}_{2}$ consumption flux during rock chemical weathering in the Zengjiang River basin is close to those in the southern slopes of the Himalaya and in some upstream watersheds of the Amazon basin. It is lower than those in watersheds with basalt and carbonate rocks in tropical and subtropical areas, and is much greater than those of catchments draining the craton terrains in temperate and

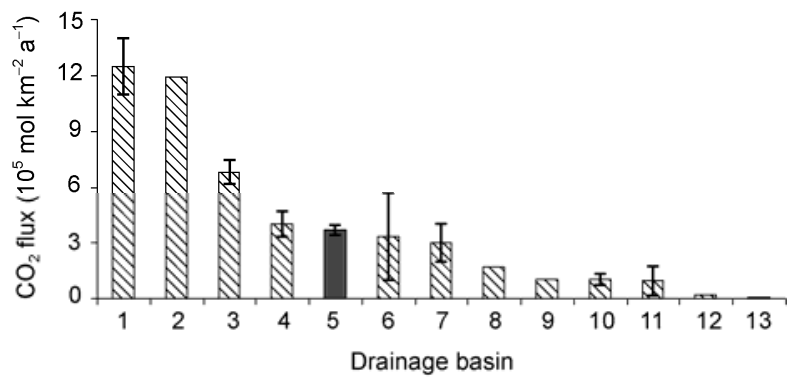

Figure 5 Comparison of $\mathrm{CO}_{2}$ consumption flux in chemical weathering in basins with different relief features and lithologies. 1, Basalt watershed in the Lesser Antilles [30]; 2, carbonate rock watershed in the Xijiang River basin [11]; 3, carbonate-rock-dominated watershed in the Nanpanjiang and Beipanjiang Rivers, the upper parts of the Xijiang River basin [31]; 4, silicate rock watershed in Okinawa Island, Japan [32]; 5, Zengjiang River basin; 6, orogenic area in the Amazon basin [10]; 7, Yamuna basin, the southern slope of the Himalaya [33]; 8, silicate rock watershed in the Xijiang River basin [11]; 9, Guayana Shield in the Orinoco basin [34]; 10, silicate-rock-dominated watershed in the Nanpanjiang and Beipanjiang Rivers, the upper parts of the Xijiang River basin [31]; 11, Honghe River basin [35]; 12, catchments draining the basement terrain of the Siberian Craton [36]; 13, catchments draining the craton terrain in the St. Lawrence basin [37].

cold-temperate zones. This indicates that atmospheric $\mathrm{CO}_{2}$ consumption flux by chemical weathering is mainly determined by the combined effects of lithology, atmospheric temperature, and precipitation within the basin.

\section{Conclusions}

Analysis of the chemical composition of the dissolved phase in the Zengjiang River enables the following conclusions to be drawn:

Silicate minerals weathering is dominant, and carbonate minerals weathering is a minor source for the dissolved load in the Zengjiang River basin as a result of the low proportion of carbonate rocks. The influences of sea-salt precipitation and anthropogenic activity on chemical runoff are not significant in the Zengjiang River basin. The chemical weathering rate of silicate minerals is constrained by lithology, atmospheric temperature, and precipitation within the basin.

Atmospheric $\mathrm{CO}_{2}$ is the primary erosive agent in rock chemical weathering. $\mathrm{H}_{2} \mathrm{SO}_{4}$ and $\mathrm{HNO}_{3}$ from acid precipitation represent a small proportion of the acid agents in rock chemical weathering in the Zengjiang River basin.

Atmospheric $\mathrm{CO}_{2}$ consumption fluxes from rock chemical weathering are (3.50-3.81) $\times 10^{5} \mathrm{~mol} \mathrm{~km}^{-2} \mathrm{a}^{-1}$ in the Zengjiang River basin, which is higher than the average value for river basins globally. The chemical weathering processes in low-middle latitude zones are influenced by the humid monsoon current of the Northern Hemisphere and constitute a significant global carbon sink in the biogeochemical cycle. 
We thank Feng $S Q$, Lai $Z H$, and Guan $Y Y$ of the Instrumentation Analysis and Research Center, Sun Yat-sen University, for their help in IC and ICP-AES analyses. As well, we would like to thank reviewers for their extensive and valuable comments. This work was supported by the National Natural Science Foundation of China (40871143, 41071054 and 40671027), an Open Fund of the China Institute of Water Resources and Hydropower Research, and the Guangdong Natural Science Foundation (7003669).

1 Berner R A, Lasaga A C, Garrels R M. The carbonate-silicate geochemical cycle and its effect on atmospheric carbon dioxide over the last 100 million years. Am J Sci, 1983, 205: 641-683

2 Bergman N M, Lenton T M, Watson A J. COPSE: A new model of biogeochemical cycling over Phanerozoic time. Am J Sci, 2004, 304 : 397-437

3 Dessert C, Dupre B, Gaillardet J, et al. Basalt weathering laws and the impact of basalt weathering on the global carbon cycle. Chem Geol, 2003, 202: 257-273

4 West A J, Galy A, Bickle M. Tectonic and climatic controls on silicate weathering. Earth Planet Sci Lett, 2006, 235: 211-228

5 Hartmann J, Jansen N, Dürr H H, et al. Global $\mathrm{CO}_{2}$-consumption by chemical weathering: What is the contribution of highly active weathering regions? Glob Planet Change, 2009, 69: 185-194

6 Raymo M E, Ruddiman W F. Tectonic forcing of late Cenozoic climate. Nature, 1992, 359: 117-122

7 Yao Z Q, Xiao G Q, Liang M Y. Global cooling controls on the chemical weathering as evidenced from the Plio-Pleistocene deposits of the North China Plain. Chinese Sci Bull, 2010, 55: 787-790

8 Schindler D W. Carbon cycling-The mysterious missing sink. Nature, 1999, 398: 105

9 Liu Z H, Dreybrodt W, Wang $\mathrm{H} \mathrm{J}$. A possible important $\mathrm{CO}_{2}$ sink by the global water cycle. Chinese Sci Bull, 2008, 53: 402-407

10 Gaillardet J, Dupre B, Louvat P, et al. Global silicate weathering and $\mathrm{CO}_{2}$ consumption rates deduced from the chemistry of large rivers. Chem Geol, 1999, 159: 3-30

11 Gao Q Z, Tao Z, Huang X K, et al. Chemical weathering and $\mathrm{CO}_{2}$ consumption in the Xijiang River basin, South China. Geomorphology, 2009, 106: 324-332

12 Gao Q Z, Tao Z. Chemical weathering and chemical runoff in the seashore granite hills in South China. Sci China Ser D-Earth Sci, 2010, 53: 1195-1204

$13 \mathrm{Wu} \mathrm{W} \mathrm{H,} \mathrm{Xu} \mathrm{S} \mathrm{J,} \mathrm{Yang} \mathrm{J} \mathrm{D,} \mathrm{et} \mathrm{al.} \mathrm{Silicate} \mathrm{weathering} \mathrm{and} \mathrm{CO}_{2}$ consumption deduced from the seven Chinese rivers originating in the Qinghai-Tibet Plateau. Chem Geol, 2008, 249: 307-320

$14 \mathrm{Wu} \mathrm{L} \mathrm{L,} \mathrm{Huh} \mathrm{Y,} \mathrm{Qin} \mathrm{J} \mathrm{H,} \mathrm{et} \mathrm{al.} \mathrm{Chemical} \mathrm{weathering} \mathrm{in} \mathrm{the} \mathrm{Upper}$ Huanghe (Yellow River) draining the eastern Qinghai-Tibet Plateau. Geochim Cosmochim Acta, 2005, 69: 5279-5294

15 Liu Z H, Dreybrodt W, Wang H J. A new direction in effective accounting for the atmospheric $\mathrm{CO}_{2}$ budget: Considering the combined action of carbonate dissolution, the global water cycle and photosynthetic uptake of DIC by aquatic organisms. Earth-Sci Rev, 2010, 99: $162-172$

16 Jiang Z C, Yuan D X. $\mathrm{CO}_{2}$ source-sink in karst processes in karst areas of China. Episodes, 1999, 22: 33-35

17 Meybeck M. Global chemical weathering of surficial rocks estimated from river dissolved loads. Am J Sci, 1987, 287: 401-428

18 Dalai T K, Krishnaswami S, Sarin M M. Major ion chemistry in the headwaters of the Yamuna river system: Chemical weathering, its temperature dependence and $\mathrm{CO}_{2}$ consumption in the Himalaya. Geochim Cosmochim Acta, 2002, 66: 3397-3416

19 Huh Y S, Tsoi M Y, Zaitsev A, et al. The fluvial geochemistry of the rivers of Eastern Siberia: I. Tributaries of the Lena River draining the sedimentary platform of the Siberian Craton. Geochim Cosmochim Acta, 1998, 62: 1657-1676

20 Meybeck M. Concentrations des eaux fluviales en éléments majeurs et apports en solution aux océans. Rev Géol Dyn Géogr Phys, 1979, 21: $215-246$

21 Goldsmith S T, Carey A E, Lyons W B, et al. Extreme storm events, landscape denudation, and carbon sequestration: Typhoon Mindulle, Choshui River, Taiwan. Geology, 2008, 36: 483-486

22 Amiotte-Suchet P A, Probst J L. Modelling of atmospheric $\mathrm{CO}_{2}$ consumption by chemical weathering of rocks: Application to the Garonne, Congo and Amazon basins. Chem Geol, 1993, 107: 205-210

23 Blum J D, Gazis C A, Jacobson A D, et al. Carbonate versus silicate weathering in the Raikhot watershed within the high Himalayan crystalline series. Geology, 1998, 26: 411-414

24 White A F, Schulz M S, Lowenstern J B, et al. The ubiquitous nature of accessory calcite in granitoid rocks: Implications for weathering, solute evolution, and petrogenesis. Geochim Cosmochim Acta, 2005, 69: 1455-1471

25 White A F, Bullen T D, Vivit D V, et al. The role of disseminated calcite in the chemical weathering of granitoid rocks. Geochim Cosmochim Acta, 1999, 63: 1939-1953

26 Mortatti J, Probst J L. Silicate rock weathering and atmospheric/soil $\mathrm{CO}_{2}$ uptake in the Amazon basin estimated from river water geochemistry: seasonal and spatial variations. Chem Geol, 2003, 197: 177-196

27 Edmond J M, Huh Y S. Chemical weathering yields from basement and orogenic terrains in hot and cold climates. In: Ruddiman W F, ed. Tectonic Uplift and Climate Change. New York: Plenum Press, 1997. 329-351

28 Lerman A, Ray B M, Clauer N. Radioactive production and diffusional loss of radiogenic Ar-40 in clays in relation to its flux to the atmosphere. Chem Geol, 2007, 243: 205-224

29 Li S L, Calmels D, Han G, et al. Sulfuric acid as an agent of carbonate weathering constrained by $\delta^{13} \mathrm{C}_{\text {DIC }}$ : Examples from Southwest China. Earth Planet Sci Lett, 2008, 270: 189-199

30 Rad S, Louvat P, Gorge C, et al. River dissolved and solid loads in the Lesser Antilles: New insight into basalt weathering processes. J Geochem Explor, 2006, 88: 308-312

$31 \mathrm{Xu} \mathrm{Z} \mathrm{F}$, Liu C Q. Chemical weathering in the upper reaches of Xijiang River draining the Yunnan-Guizhou Plateau, Southwest China. Chem Geol, 2007, 239: 83-95

32 Vuai S A H, Tokuyama A. Solute generation and $\mathrm{CO}_{2}$ consumption during silicate weathering under subtropical, humid climate, northern Okinawa Island, Japan. Chem Geol, 2007, 236: 199-216

33 Singh S K, Sarin M M, France-Lanord C. Chemical erosion in the eastern Himalaya: Major ion composition of the Brahmaputra and $\delta^{13} \mathrm{C}$ of dissolved inorganic carbon. Geochim Cosmochim Acta, 2005, 69: $3573-3588$

34 Edmond J M, Palmer M R, Measures C I, et al. The fluvial geochemistry and denudation rate of the Guayana Shield in Venezuela, Colombia, and Brazil. Geochim Cosmochim Acta, 1995, 59: 3301-3325

35 Moon S, Huh Y, Qin J, et al. Chemical weathering in the Hong (Red) River basin: Rates of silicate weathering and their controlling factors. Geochim Cosmochim Acta, 2007, 71: 1411-1430

36 Huh Y S, Edmond J M. The fluvial geochemistry of the rivers of Eastern Siberia: III. Tributaries of the Lena and Anabar draining the basement terrain of the Siberian Craton and the Trans-Baikal Highlands. Geochim Cosmochim Acta, 1999, 63: 967-987

37 Millot R, Gaillardet J, Dupre B, et al. Northern latitude chemical weathering rates: Clues from the Mackenzie River Basin, Canada. Geochim Cosmochim Acta, 2003, 67: 1305-1329

Open Access This article is distributed under the terms of the Creative Commons Attribution License which permits any use, distribution, and reproduction in any medium, provided the original author(s) and source are credited. 